\title{
Tommy Koh and the U.S.-Singapore Free Trade Agreement: A Multi-Front "Negotiation Campaign"
}

\section{Citation}

Green, Laurence A., and James K. Sebenius. "Tommy Koh and the U.S.-Singapore Free Trade Agreement: A Multi-Front 'Negotiation Campaign'." Harvard Business School Working Paper, No. 15-053, December 2014.

\section{Permanent link}

http://nrs.harvard.edu/urn-3:HUL.InstRepos:13596848

\section{Terms of Use}

This article was downloaded from Harvard University's DASH repository, and is made available under the terms and conditions applicable to Open Access Policy Articles, as set forth at http:// nrs.harvard.edu/urn-3:HUL.InstRepos:dash.current.terms-of-use\#OAP

\section{Share Your Story}

The Harvard community has made this article openly available.

Please share how this access benefits you. Submit a story.

Accessibility 
H A R VAR D

\section{Tommy Koh and the U.S.- Singapore Free Trade Agreement: A Multi-Front "Negotiation Campaign"}

Laurence A. Green

James K. Sebenius

\section{Working Paper}

15-053

December 16, 2014 


\section{Tommy Koh and the U.S.-Singapore Free Trade Agreement: A Multi-Front "Negotiation Campaign" Laurence A. Green and James K. Sebenius* \\ December 16, 2014, v2.2}

Abstract: Complex, multiparty negotiations are often analyzed as principals negotiating through agents, as two-level games (Putnam 1988), or in coalitional terms. The relatively new concept of a "multi-front negotiation campaign" (Sebenius 2010, Lax and Sebenius, 2012) offers an analytic approach that may enjoy descriptive and prescriptive advantages over more traditional approaches that focus on a specific negotiation as the unit of analysis. The efforts of Singapore Ambassador-At-Large Tommy Koh to negotiate the United StatesSingapore Free Trade agreement serve as an extended case study of a complex, multiparty negotiation that illustrates and further elaborates the concept of a negotiation campaign.

Keywords: Tommy Koh, negotiation campaign, fronts, negotiation, diplomacy, multiparty negotiations, free trade, Singapore, international relations, United States, Special Trade Representative

On May 6, 2003, having ironed out the final details, Prime Minister Goh Chok Tong and President Bush formally signed the U.S.-Singapore Free Trade Agreement. At the end of July, both houses of Congress ratified the United States-Singapore Free Trade Agreement. Of 100 Senators and 435 congressmen, 66 and 272 voted in favor of the agreement respectively.

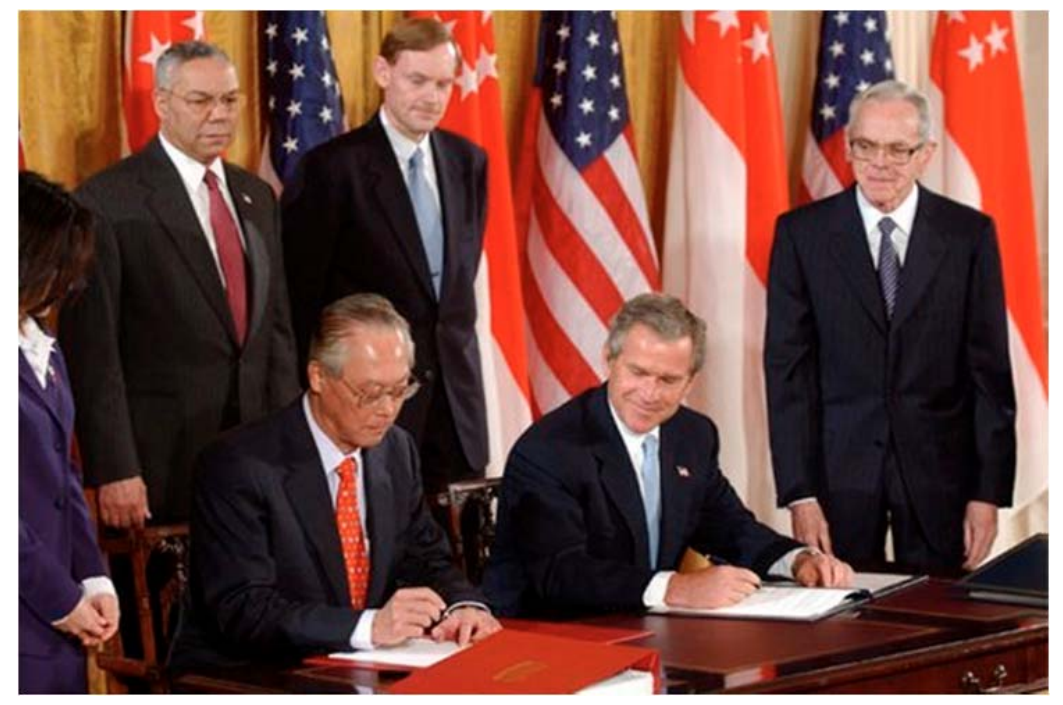

Figure 1: President George Bush and Prime Minister Goh Chok Tong Signing the U.S.-Singapore Free Trade Agreement, May 6, 2003.

An extremely naïve observer might imagine that the two heads of government had personally negotiated the agreement just as a dealer and a consumer might have haggled over a car purchase. An only slightly less naïve analyst would know that, at a minimum, the deal was worked out between the staffs of the two leaders. And, indeed, the great bulk of academic work on negotiation focuses on the two-party case, sometimes with the wrinkle of principals negotiating through agents. In such work, the "unit of analysis" that negotiation scholars primarily examine is the individual

*Copyright $@ 2014$ by James K. Sebenius. James K. Sebenius (jsebenius@hbs.edu) is the Gordon Donaldson Professor of Business Administration at Harvard Business School. Laurence A. Green (agreen.alex@gmail.com) is a Research Associate at the Harvard Business School. 
deal. With this focus, they analyze the process by which parties interact, their deeper interests, communication patterns, possible agreements, and other factors that may influence the outcome of a specific interaction.

A traditional political scientist with an international relations bent might indulgently smile even at this slightly more complex characterization, knowing full well that Singapore and the United States had been engaged in a classic "two-level game," crystallized by Robert Putnam (1988) in which (international) negotiations "across the table" had to be ratified by (domestic) negotiations "behind the table."

While these characterizations are not wrong, they are highly incomplete as accounts of this and many other international negotiations. Indeed, the concept of a multi-front "negotiation campaign" often better captures the reality of complex international negotiations. While doing one deal well requires a certain set of skills, designing and executing the type of broader negotiation campaign that we will examine in this paper requires artfully putting a number of deals together, often on multiple fronts, to realize a larger result, typically an ultimate target agreement with sufficient support to make it stick. When the unit of analysis shifts from the individual deal to the campaign, a new set of challenges arises, first explored in Sebenius (2010), later elaborated in Lax and Sebenius (2012). The extended USSFTA case study developed in this paper adds to a growing number of public and private sector negotiations analyzed as negotiation campaigns.

The need to negotiate multiple, related deals is not new to negotiation theory or practice. For example, linkage has always been a useful concept, though mainly as a way to exert leverage from one area on another or to assemble a beneficial package of smaller deals (See, e.g., Sebenius 1983). Similarly, coalition building sometimes requires multiple deals, often assembled through careful sequencing (see, e.g., Sebenius 1996). Such concepts can help in multi-deal situations, but negotiators can find special value in thinking in terms of campaigns, with fronts that must combine to generate enough support for ultimate target agreements. As the USSFTA case will illustrate, several steps are involved, at least conceptually, in orchestrating a successful negotiation campaign:

1. Envision the ultimate target deal. What is the ultimate target deal and which parties must support it? Will a single authoritative "yes" do the trick, or does lasting success require a larger winning coalition of support?

2. Identify key parties. Mapping backward from the ultimate target deal, what internal and external parties must be involved, which potential players might usefully be drawn into the process, and which could possibly be involved in various supporting-or opposing-negotiations? Will building a winning coalition require conscious moves to thwart potential blocking coalitions?

3. Identify "fronts." On what bases can these dozens of actually and potentially involved parties usefully be grouped into a manageable number of fronts? Are the parties of a similar kind (e.g. all financial players, or all from the executive branch)? or in similar sectors? Are they organizationally related (e.g., staff from different agencies of a state government)? Do they share key interests? Are there other attributes that would make it useful to group several individual parties for the purposes of campaign strategy? While a front can consist of an individual party, it will more often be a collection of parties that simplifies strategic reasoning about the complex whole. Negotiations will be necessary both within fronts and among them. 
4. Assess any interdependencies among fronts. Are the fronts largely independent of each other, or can they affect each other, whether positively or negatively? For example, is provisional agreement at the corporate and political levels helpful or even necessary for successful negotiations, or vice versa? Does progress or backsliding in negotiations within one front change the odds of success for negotiations in other fronts? If so, how?

5. Orchestrate the negotiations among fronts. How should the broader fronts be orchestrated with respect to each other so they come together to best set up the ultimate target deal? For example, should the various fronts be engaged sequentially or in parallel, or should a hybrid approach be used? If sequentially, what is the most promising order of emphasis? Should negotiations within one front be undertaken quietly and privately, or publicly?

A great deal of analysis and conceptual development is needed to answer these kinds of questions for campaigns with different characteristics. In essence, whenever a number of individual agreements must be aggregated to gain sufficient support for an ultimate target agreement, it may be useful to craft a broader negotiation campaign within which a more manageable number of fronts can be orchestrated. As the most promising campaign architecture emerges, it will be able to powerfully clarify and guide what otherwise might be dozens of ad hoc, even chaotic, individual negotiations.

As the following extended exploration of the Koh-USSFTA case will show, sophisticated international negotiators don't just do a number of deals, hoping that they somehow add up; instead, they design and wage a carefully structured negotiation campaign.

\section{An Unfulfilled Dream}

As Ambassador Tommy Koh prepared to return home to Singapore in late 1991, he reflected on two decades of living in America. He had arrived in New York in 1968 at age 31, representing Singapore as Ambassador to the United Nations. ${ }^{1}$ In the ensuing years, he had earned a reputation as a top-tier negotiator, widely respected for his ability to resolve global disputes, sometimes involving thousands of diplomats. ${ }^{2}$ Among his many achievements, Koh had chaired some of the largest negotiations in the world to date; the Third United Nations Conference on the Law of the Sea, leading the drafting and ratification of a "constitution for the oceans" as well as chairing both the preparatory commission for and the massive Rio "Earth Summit" itself (more precisely, the "U.N. Conference on Environment and Development"). ${ }^{3}$ Yet for all his success, one of his goals remained unfulfilled. For six years as Singapore's Ambassador to the United States, Koh dreamed of striking a free trade agreement (FTA) between the Southeast Asian nation and the global superpower. ${ }^{4}$ Instead, he was going home empty-handed. ${ }^{5}$

Born in 1937, Koh was raised in a time of extraordinary upheaval and change. ${ }^{6}$ As a boy he lived through the waning of the Great Depression and the Japanese occupation of Singapore during World War II. He came into adulthood amidst the lengthy and difficult transition from colony to independent statehood. In 1963, Singapore joined the Federation of Malaysia in gaining independence from the United Kingdom; two years later, the city-state split from Malaysia under the leadership of Lee Kuan Yew. During that time, Koh rose through the ranks of Singapore's legal class, earning a law degree at the University of Malaya experiencing life in America for the first time as a graduate student at Harvard Law School, and pursuing post-graduate work at Cambridge University. ${ }^{7}$ 
Four years after graduating from Harvard, Koh returned to the United States as Ambassador and Permanent Representative to the United Nations, and aside from a brief period as the Dean of the Faculty of Law at the University of Singapore, he spent the next twenty years in the United States. ${ }^{8}$ During this time, Koh forged close relationships, working with Americans first-hand, and his experience gave him the belief that Singapore would benefit substantially from a substantive, strategic economic agreement between the two nations.

Koh's years as Ambassador to the United States paralleled the emergence of Singapore, a small, republic of 3 million people in 1990, as a growing regional economic power. ${ }^{9}$ A territory of only 275 square miles along the Singapore Straits, the country was becoming a hub for shipping, finance, energy, hi-tech manufacturing, and biotechnology. ${ }^{10}$ During Koh's years in Washington D.C., Singapore's economy grew substantially, and the nation's leaders sought to anchor the stability of their expanding economy by forging close ties with a number of powerful trading partners. ${ }^{11}$ In 1990, Koh and his counterparts negotiated normalization of relations with China, successfully reaching an agreement while finessing their powerful neighbor's strong preference for radically diminished Singaporean links to Taiwan, China's "rebellious province." 12 Koh believed that an important achievement would be a United States-Singapore Free Trade Agreement (USSFTA), opening Singapore's still-small economy to the largest marketplace in the world, but the circumstances to embark on such a deal were never right. As he packed his bags and headed home, Tommy Koh knew that his dream would have to wait.

Renowned for his quiet, compassionate, amiable, yet firm approach to forging consensus, Koh moved between myriad career positions in the nine years after leaving the United States, buoyed by a deep empathy for the needs of others, a love for arts and culture, and a tireless curiosity about the world at large. He returned to academic work as director of Singapore's Institute for Policy Studies, and became the founding chairman of The Singapore National Arts Council. ${ }^{13}$ He also continued to work abroad, serving as a representative of Singapore's Ministry of Foreign Affairs, Chairman of the United Nations Conference on the Economy and Development (UNCED) from 1990-92 and Special Envoy for the U.N. Secretary General in helping to mediate disputes between the Russian Federation and the Baltic states. ${ }^{14}$

\section{Reviving the U.S.-Singapore Free Trade Agreement}

Throughout the 1990s, the possibility of negotiating a USSFTA grew even more remote. Relations between the two nations soured in 1994 when a young American living in Singapore was punished with caning-a painful, sometimes bloodying and scarring form of whipping across the buttocks with a rattan-after being convicted for what many in the United States regarded as minor vandalism. ${ }^{15}$ The 1997 appointment of Steven Green as Ambassador to Singapore helped to improve the strained diplomatic ties, but the possibility of striking such a trade agreement seemed distant.

In November 2000, the U.S. Special Trade Representative Charlene Barshefsky stopped in Singapore on her way to join President Bill Clinton at the Asia-Pacific Economic Cooperation (APEC) conference in Brunei. In a meeting with Green, the two hatched a plan and quickly presented it to Lee Kuan Yew and Prime Minister Goh Chok Tong. The time was right, they said, for a U.S.Singapore Free Trade Agreement (USSFTA). They suggested that Goh present the idea to Clinton in Brunei. ${ }^{16}$

It was a bold idea. In the decade following the collapse of the Soviet Union, the United States had become the world's sole economic and military superpower. Countless nations sought an agreement that would open access to American markets, create favorable trade conditions, lower tariffs, and 
ease travel to and from the United States. The list of nations being considered for an FTA by the Clinton Administration was ranked by priority, and safeguarded by Secretary of State Madeline Albright and National Security Adviser Sandy Berger. Singapore was on the list, but nowhere near the top. Barshefsky and Green had not informed their superiors of their proposal. ${ }^{17}$ And the clock was running out on the Clinton presidency, with George W. Bush to take the reins of power in a few short months.

Despite the break with protocol, Barshefsky and Green's overture was not unfounded. The Clinton Administration had recently ratified free trade agreements with Israel and Jordan, as well as regional pacts like the North American Free Trade Agreement (NAFTA). ${ }^{18}$ It was exploring FTAs with Latin American countries such as Chile. Moreover, economies across Asia were expanding, as were the strategic and diplomatic ties between nations in the region. Despite Asia's increasing influence and power, the United States had no free trade agreements with an Asian nation. With annual American direct investment in Singapore's economy that would reach $\$ 27$ billion by 2001, a population of thousands of Americans living in Singapore, and a strong economy comprised of industries with ties to American interests, a free trade agreement could benefit both countries. ${ }^{19}$ For Singapore, reaching an agreement also created an opportunity to lead the way in drawing the regional consortium of Southeast Asian nations (ASEAN) into closer ties with the United States. ${ }^{20}$

Goh and Lee did not hesitate. With no formal meeting arranged between Goh and Clinton at the APEC summit and no time on the tightly choreographed schedule for such a meeting, they needed to find a way to get the two leaders alone with each other long enough for Goh to pitch the agreement.

\section{A Midnight Round of Golf}

On the afternoon of November 16, 2000 Singapore Ambassador-at-Large Tommy Koh was out for a walk, taking a break from lecturing at a Chinese university, when he received a phone call from his Trade Minister George Yeo. Yeo had important news and a proposal. ${ }^{21}$

The previous evening at the APEC state dinner in Brunei, Singapore Prime Minister Goh Chok Tong had approached U.S. President Bill Clinton and proposed a late-night round of golf. An avid golfer, Clinton readily accepted and near midnight after the state banquet, the two leaders headed to the course. Goh and his aides watched anxiously as a storm rolled across Brunei, fearful that their carefully planned window of opportunity might be rained out, but just after midnight the storm lifted and the two headed onto the course. ${ }^{22}$

When they broke for coffee at 2:00 a.m., Goh made the case for a US-Singapore Free Trade Agreement (USSFTA). A deal with Singapore would be the first in Asia, Goh argued, and would tangibly demonstrate how the U.S. valued Asia. Moreover, as a small, very open, market-oriented economy, an FTA with Singapore should be "easy" to negotiate. Its terms should be very appealing to the U.S. and, as the first U.S.-Asian FTA, would set an excellent precedent for other Asian trade deals. Goh's case was persuasive and Clinton readily agreed. In the waning days of his final term, Clinton told Goh that it could be done. Two months remained until his successor, George W. Bush, would take office. That morning, Goh and Clinton made the announcement--to the surprise of Madeleine Albright, his Secretary of State, and Sandy Berger, his National Security Advisor. This was followed by a press release that the two nations would negotiate a USSFTA. ${ }^{23}$

Trade Minister Yeo followed his update with a request: would Tommy Koh accept the position as Singapore's chief negotiator in the talks to draft and ratify a USSFTA? Koh's long-time dream of such 
a deal now seemed to be moving into reach and he had the opportunity to make it a reality. He readily agreed, and prepared to return to the United States. ${ }^{24}$

One of Singapore's most adept representatives in dealing with the United States, Koh later jokingly reflected that Goh's golf match with Clinton leading to the impromptu announcement of an agreement, "was a coup," but he knew that a finalized agreement between the two countries was far from certain. ${ }^{25}$ While Singapore's successful "jump the FTA queue" maneuver moved the city-state up in priority, it also left some level of animosity among employees in the executive branch of the U.S., as well as in the Congress, which preferred consultation to edict. Significant barriers, misperceptions, and hard feelings lay in the path before them. Despite support for an agreement by Singapore's leadership, complex internal negotiations lay ahead with companies and government agencies whose interests could be adversely affected. Furthermore, Koh needed to create a team that could negotiate capably with the Americans. Nor were reservations limited to Singapore's side.

Prime Minister Goh placed his confidence in Koh to know how to navigate these confusing, treacherous waters and reach an agreement with the United States. Less familiar with the American treaty process, Goh had accepted Clinton's assurance at face value, relaying the message to Koh with an ominously emphatic farewell, "get the job done before you come home." 26 After frenzied preparations on the issues involved in a USSFTA, Koh prepared to leave Singapore for Washington D.C. in December 2000 with a large delegation. As he relaxed into the comforts of a long Singapore Air flight to the United States, he began putting the elements of a negotiating strategy in place.

\section{An Empty Capitol}

Likely having in mind the relatively narrow Jordan FTA as a model, President Clinton had remarked to Prime Minster Goh that an agreement could be reached in two months. Having spent much of his career in the United States, Tommy Koh touched down in the capitol with a firm sense of what lay in store instead, especially given the far larger and more complex commercial dealings between Singapore and the United States. ${ }^{27}$

Clinton's second and final term in office was coming to an end. An acrimonious election for the president's successor had resulted in the election of George W. Bush, a member of the opposing political party. The new president would take office in late January and even though two months remained, Koh knew that this would not be enough time to complete an agreement before the transition. He also knew that any proposed agreement would be viewed more favorably by Bush's team if it were seen as distinct from whatever the Clinton administration had envisioned as an FTA. ${ }^{28}$

Looking out across an empty U.S. capitol, awaiting the transition of the elected and appointed leadership of the United States federal government, Koh picked up the phone and called Prime Minister Goh and told him it could not be done. ${ }^{29}$ It would take far longer than two months to reach an agreement and, given the transition, little could happen at all in Washington any time soon. Goh asked Koh to push ahead anyway, for as long as it took. With that, Tommy Koh set about with his colleagues building a complex, multi-headed, supportive coalition on behalf of a United StatesSingapore Free Trade Agreement.

\section{Negotiating with the United States ${ }^{30}$}

For foreign diplomats, Koh had come to realize, negotiating with the United States is an altogether different process than anywhere else in the world. In many nations the drafting, negotiation, and 
ratification of free trade agreements is entirely driven by the staff or office of the president or prime minister. In the United States, agreements must be reached through direct negotiations with the Office of the Trade Representative (USTR), a presidential appointee. Yet the USTR is primarily responsible for negotiating an agreement that requires the formal or informal consent of many other parties. Even as the language of an agreement is hammered out with the country on the other side of the deal, U.S. interest groups can have significant influence over what is or is not discussed. ${ }^{31}$ Reflecting on his time as Ambassador to the United States, Koh remarked:

"When I left [the United Nations in] New York for [the U.S. government in] Washington, I thought I was leaving a multilateral post for a bilateral one. However, although I am now dealing with only one government instead of 158, the U.S. Government is, in a very real sense, a multilateral system. I do not think there is another government in the family of democratic societies in which power is so decentralized and dispersed, and in which so many institutions and individuals are involved in or have inputs into the making of policy and the implementation of decisions and programmes." 32

For foreign diplomats and leaders, these unique characteristics of American democracy could make trade negotiations especially challenging. An FTA required lengthy public consultation, the de facto consent-or at least passive acquiescence-of a majority of 31 citizen advisory groups, negotiations with the USTR, support from other federal agencies, and the approval of both the United State Senate and House of Representatives. ${ }^{33}$ And, of course, these "external" negotiations with various U.S. interests had to be meshed with sometimes challenging "internal" negotiations.

In short, Koh, Singapore's Ambassador the United States, Chan Heng Chee, and their teams would coordinate, together with their political superiors, on what Koh would later call a "multi-front negotiation campaign." Looking to the desired endpoint of this process, they could envision President Bush and Prime Minister Goh negotiating the final details, then shaking hands and inking a deal that would attract sufficient House and Senate support for passage and implementation. Yet to get there, the Singaporeans would have to negotiate, formally and informally, on several broad fronts: with the executive branch, the Congress, a non-monolithic business community, fractious elements of civil society such as organized labor, as well as among key factions in Singapore.

Having served for six years as Singapore's Ambassador the United States, Koh knew that he was entering negotiations having already upset a critical constituency. Not only do citizens, business groups, and elements of civil society have extraordinary influence over the potential outcome of trade negotiations, so do their representatives in the United States Congress. Technically a treaty, a free trade agreement must be presented to both houses of Congress by the president for ratification. In the case of the USSFTA, the proposal to enter negotiations had been rushed by the window of opportunity presented by Goh and Clinton's golf match. In the process, Singapore had vaulted ahead of numerous other nations waiting in line for a potentially valuable free trade agreement with the United States. ${ }^{34}$

A sensitive issue, the process of determining the order of nations hoping to enter into FTA talks typically entailed consultations between senior administration officials and congressional leaders, with whom many nations seeking an FTA had supporters. By jumping ahead, Singapore had slighted congressional representatives, cutting in line without the courtesy of consulting with them first. ${ }^{35}$ 


\section{The Executive and Congressional Fronts.}

Rather than wait for irritated officials to return to Washington and attack even the prospect of an agreement, Koh and Ambassador Chan, took the two-month transition of power to rebuild ties and begin facilitating the creation of a "Singapore caucus" in the House of Representatives. They sought out potential allies, carefully selecting potentially receptive representatives with influential constituencies and powerful positions on congressional committees. It was the beginning of the unprecedented formation of a group that would ultimately be comprised of, what to many observers, was an astonishing 59 representatives from both major political parties-a matter of special importance given the traditional Democratic suspicion of free trade deals. ${ }^{36}$

The quiet of the winter recess in Washington was deceptive. While the Washingonians were out of town, Koh and his team did not waste time. Among other preparatory moves, he carefully coordinated with his deputy negotiator, Ong Ye Kung, as well as with Ambassador Chan. ${ }^{37}$ Koh actively reached out to his "Republican friends" such as Paul Wolfowitz, Richard Armitage, and Robert Zoellick. He also anxiously hoped that key trade-related appointees of the new administration might be old friends from his earlier days in Washington. He was not disappointed.

Assistant Special Trade Representative Ralph Ives, was well-liked and well-respected by the Singapore delegation. Ives understood the challenges of negotiating a free trade deal as well as Koh, later writing, "FTA negotiations are tough. The issues involved are concrete. At stake are real people, real investments, real jobs, real products, real property, and real ideas." 38 Meeting for the first time in late 2000, Koh and Ives saw eye to eye. It was a relationship that would later allow difficult conversations to take place openly and honestly. ${ }^{39}$

Koh was especially pleased by the appointment of the new trade representative, Robert Zoellick. A long-time U.S. government official with extensive economic expertise, Zoellick had served as Undersecretary of State for Economic and Agricultural Affairs during Koh's tenure as Ambassador the United States. ${ }^{40}$ The two knew each other reasonably well. In fact, Zoellick had been an early proponent of an FTA between the United States and Singapore, suggesting the idea in 1992 during the presidency of George H.W. Bush. ${ }^{41}$

As the new administration came to Washington, the teams entered two rounds of negotiations, setting a framework, and identifying the 21 significant issue-areas that would need to be addressed by an FTA. ${ }^{42}$ With an open economy, the Singaporeans were able to identify the potential for a substantive agreement on many economic issues. They hoped to be the first Asian nation to negotiate an FTA with the United States, ideally with fellow members of the Association of Southeast Asian Nations (ASEAN) following suit. ${ }^{43}$ The new American administration shared this goal, believing that a USSFTA could be a desirable model FTA from which to structure future agreements in the region. ${ }^{4}$

The goals of both sides fundamentally altered the kind of FTA being proposed. Of the shift in approaches between the two administrations, Ives said, "the Clinton Administration [...] envisaged an FTA modeled on the U.S.-Jordan FTA, which was purposefully modest in scope." The Bush administration, "decided to seek a comprehensive world-class agreement."45

The promise of an expanded agreement held value to both sides but with so many substantive issues at stake, the USSFTA would require significantly greater time and resources than the U.S.Jordan model. Koh had known it would take more than two months. It was increasingly evident that many - it would turn out to be 11 - rounds of negotiations lay ahead over the next 24 months. ${ }^{46}$ 
From the outset, Koh and Chan found a close ally in Democrat Solomon Ortiz, a Texas congressman whose district was home to an outpost of a large Singaporean maritime technology company. With Ortiz's support, a Republican co-chair for the Singapore Caucus was found. Thereafter, Chan regularly contacted representatives and their senior staffs in order to garner support and provide updates on the progress of the negotiations. "Failure to maintain this process," wrote Chan, "could end up with the FTA mired in the Committee or a negative vote because concerns were not addressed along the way."177 Instead, regular communication led to the anticipation of potential stumbling blocks and the ability to pre-empt them. Over the course of the negotiations, Koh's team met with 353 congressmen and 78 senators. ${ }^{48}$

\section{The U.S. Business Front}

Buoyed by the appointment of Zoellick and Ives, Koh and his team were acutely conscious of the importance of looking beyond direct negotiations to the powerful constituencies arrayed around the USTR. Tremendous domestic pressures could be exerted on the USTR, especially if a coalition opposed an agreement. Elements of the same business community Singapore hoped to access with an FTA could, if their interests felt threatened, mobilize against Singapore and challenge the deal. If Koh overcame these pressures in this form, he knew that opponents would simply fight him again in Congress ${ }^{49}$ He later wrote, "I know of no other country in the world in which business enjoys such a pervasive influence as the United States. There is truth in the dictum that the business of America is business." ${ }^{50}$ Instead of waiting to see who might object, he decided that his team should reach out to American business and seek to minimize any potential business opposition.

In order to protect domestic and international interests, the American business community maintains a naturally close relationship with the Office of the Special Trade Representative, providing advice about the potential effects of treaties on day-to-day business. Koh needed to the U.S. business community, at least on balance, to strongly favor an agreement.

Koh and Chan invited potential business allies to a "brainstorming discussion" where they proposed the creation of a USSFTA Business Coalition to support their efforts. ${ }^{51} \mathrm{~A}$ global hub for shipping, hi-tech, biotechnology and manufacture, Singapore's important U.S. business connections were leaders in American industry including petroleum giant ExxonMobil, shipping leader UPS, and Boeing, the world's largest aerospace company. These three companies now took the helm, seeking out other supporters in the American business community for a group that would ultimately count 114 major companies as members. ${ }^{52}$

Koh and Chan also actively pursued the support of the American Chamber of Commerce's outpost in Singapore, AMCHAM. Representing 1,500 members, including most Fortune 500 companies, and over $\$ 25$ billion of investment in the Singapore's economy, AMCHAM appeared to be a natural ally. The organization's leaders agreed to survey their members to gauge support for a USSFTA, but Singapore's prior successes now emerged as a disadvantage. ${ }^{53}$ Respondents felt that Singapore was already a positive business environment, they were reluctant to support any changes, even if there was the promise of greater gains. ${ }^{54}$ Koh and Chan continued to pursue the group's support, however, and as signs emerged of the new administration's interest in an FTA, along with the formation of the U.S.-based business coalition, AMCHAM ultimately chose to join the business coalition..$^{55}$

The existence of the coalition sent a confident signal to the USTR, creating openings for agreement and allowing Koh and Chan to quickly identify potential concerns and confront them directly, 
helping the Singaporeans to, "untie some of the knots," according to Chan, "produced in the trade negotiations." 56

In one instance a senior Singaporean leader asked Koh how the negotiations were proceeding and Koh replied that he faced opposition from a Chicago-based company. He explained that he was, "down to a few sticking points." When the leader asked what the problem was, Koh responded that it was all about chewing gum. Thinking that Koh was teasing him, the leader turned to walk away, but Koh rushed to keep up. It was no joke, he said. ${ }^{57}$

Wrigley, one of America's leading chewing gum manufacturers, had a serious problem with Singapore, a fastidious nation with severe penalties for public littering and specific bans on the availability of products that might contribute to its spread. Counted among these products was chewing gum, which not only was hard to remove when stuck to surfaces in public places, but was banned after gum was stuffed onto the censors of a subway door, causing an unusual delay for Singapore's state-of-the-art subway system..$^{58}$ The government's response included mandatory court appearances for chewing gum offenders and fines of over $\$ 200$ per offense. ${ }^{59}$ For years, there had been little recourse for Wrigley in Singapore, but now its potential power was two-fold. It could intervene with the USTR, and they could turn to their member of congress, the powerful chairman of the House Subcommittee on International Trade. ${ }^{60}$

Yet, as the business coalition began to solidify, Koh identified Wrigley's concerns far in advance and focused his efforts on addressing them before they could impede the negotiations. Meeting with the company's representatives a satisfactory bargain was struck. After first agreeing only to the sale of gum in pharmacies with a doctor's prescription, the Singaporeans ultimately agreed to the general availability of healthy brands of gum. ${ }^{61}$ This chewing gum focus was but one of the places in which Singapore's negotiators sought out and addressed the concerns or interests of many specific American companies, such as Citibank that wanted (and got) assurances that it could operate as a fully "local" bank in Singapore.

\section{The Civil Society Front and the "Nightmare Scenario" 62}

Koh had identified business groups that might block an agreement and, like Wrigley, attempted to head them off one at a time, reducing the potential that Singapore might face intractable opposition, but there was still work to be done. Most importantly, there was still the possibility that the entire agreement could be derailed in what he nervously anticipated and came to call "the nightmare scenario." 63

To Koh, the nightmare scenario would be a coalition of progressive opposition groups whose combined power could sway the general public, and consequently their representatives, against an agreement. Koh envisioned three major opposition groups that might independently oppose a USSFTA; environmental groups, human rights advocates, and organized labor unions. Beyond any ideological objections to markets and free trade, historically, each of these groups had reasons to be suspicious of any given trade deal: unions feared exploited and cheap labor abroad would lead to U.S.-job destroying imports; environmentalists feared that lower standards abroad would effectively undercut higher U.S. rules; and human rights activists were always alert to abuses such as de facto slave labor forced to make goods for export to the United States. If mobilized to act not only independently, but should they somehow coalesce into a determined blocking entity, these three groups could likely derail the USSFTA. ${ }^{64}$ 
Koh watched the environmental groups closely to see if they were poised to act, but came away confident that they would not. His track record having chaired the Rio Earth Summit, the largest and most successful United Nations negotiations on the environment, served him in good stead with the green movement. Trusted and respected, he faced no active opposition, and when he looked to the human rights organizations, perhaps a bit puzzlingly, he saw little interest in or opposition to a USSFTA.${ }^{65}$ Organized labor, however, was a different story.

Singapore's lack of a minimum wage made the country an open target for the powerful American unions and the unions could organize opposition in Congress, that might easily overwhelm Koh's Singapore group. ${ }^{66}$ Yet during his time in Washington a decade earlier, Koh had courted leaders of the powerful AFL-CIO union, even hosting them for dinner at his residence. Consequently respected by union leaders and known to them as a person rather than an anonymous bureaucrat, Koh took the opportunity to reach out to the leadership, meeting their concerns head-on. ${ }^{67}$

Koh encouraged Singapore's trade union to approach AFL-CIO leaders to undertake an observational mission in Singapore. ${ }^{68}$ Touring them through factories and plants they were shown the working conditions for laborers. Koh hoped the effort would signal transparency, build trust and also show that serious workplace violations were not endemic in Singapore. Appreciative of his efforts and encouraged by the conditions on the ground, the leaders still voiced opposition. As a matter of policy and ideology, the unions refused to support free trade agreements.

While Koh understood that organized labor could not publicly support an agreement, but given the fact that the deal could succeed without their approval, could they agree not to fight him either directly or through their allies in the U.S. Congress or to exact retribution on members of Congress who voted in favor? They agreed and Koh's nightmare scenario was averted. ${ }^{69}$

\section{Negotiating the "Home" Front (Singapore)}

While focused intently on multiple U.S. fronts, executive, , the Singaporeans also needed to address difficult internal negotiations over the text. The unexpectedly comprehensive nature of the FTA was unprecedented and Ralph Ives feared that, "Singapore often had to wait-sometimes for months - for the U.S. side to develop a position on a particular issue."70

Koh reflected that senior Singaporean officials had to do the same and it was sometimes difficult. In frequent consultations, Singapore's cabinet had to "review policies [and] change some laws, which people were not willing to concede. The internal negotiation was quite challenging. We had to even bend some things that we were not willing to concede to any other country."71 For example, not only did highly symbolic issues like chewing gum call for changes in Singaporean policies but also provisions that would specifically benefit U.S. financial institutions. The most significant of these included opening Singapore to American banks, lifting a prohibition on the types of services they offer and the number of locations allowed in Singapore per bank. ${ }^{72}$

\section{Dinner Diplomacy Closes the Gap}

In Washington, Koh's team worked day and night to reach an agreement on the 21 issues facing the working groups. Grappling with challenging, intricate details, they realized early on in the process that some important advances could only happen by going outside of the formal negotiating process. Dinner or "makan diplomacy" was often a helpful vehicle. ${ }^{73}$ Encouraged by Koh, his negotiators built trust and overcame impasses time and again by meeting their counterparts for 
informal discussions in the restaurants of Washington and other cities where Singaporean and American interests met.

In January 2003, the two sides produced an agreement and with it, Koh's team prepared to see it presented to the President and to his Prime Minister. After reviewing the treaty, Bush notified Congress of his intent to submit the agreement to them for review and ratification. ${ }^{74}$

\section{"A Multi-Pronged Campaign"75}

Having worked for years to cultivate well-organized, large constituencies, the Singaporeans' supporters in business and in Congress now intensified their supportive actions. From the outset, they received encouraging signs. When the USTR called for input on the FTA, letters of support poured in from many quarters, including-unprecedentedly-from seven state governors and the state treasurer of California. ${ }^{76}$ Singapore's delegation delivered talking points at think tanks and spoke at length with reporters, while members of the business coalition mobilized to encourage the congressional representatives to vote in favor of the FTA. ${ }^{77}$ Senior leaders, including George Yeo and Robert Zoellick met directly and on the margins of other meetings around the world to advance the FTA.

In March 2003 the USTR agreement was released to the public for comment. The business coalition held firm and while the unions still objected to the FTA, they did so relatively quietly. On May 6, 2003, after the close of public comment, Prime Minister Goh Chok Tong and President Bush formally signed the agreement. Only one step remained. Bush sent the treaty to the House of Representatives and Senate for ratification. At the end of July, both houses of Congress ratified the United States-Singapore Free Trade Agreement. Of 100 Senators and 435 congressmen, 66 and 272 voted in favor of the agreement respectively. A sweeping affirmation, the FTA passed with over thirty more votes in the House of Representatives than either NAFTA or the bill authorizing the normalization of trade relations with China ${ }^{78}$ After nearly two decades, Koh had achieved his dream. ${ }^{79}$.

The USSFTA signified an important shift in relations between the United States, Singapore, and the entirety of East and Southeast Asia. The first trade agreement of its kind in Asia, the treaty achieved what both sides had hoped, creating a model for future agreements across the region. It also had a notable impact on Singapore's economy and trade relations with the United States. The agreement ensured the elimination of tariffs on goods, resulting in hundreds of millions of dollars of savings for major industries on both sides. Intellectual property and skilled labor visa agreements ensured a strengthening of ties between businesses engaged in hi-tech manufacturing. In addition, agreements on value-added products and shipping through Singapore held the promise of empowering Singapore as a regional hub through which goods could pass more easily to the United States. ${ }^{80}$

Reaching the agreement was not without difficulty. "Some of my ASEAN colleagues scolded me," said Koh, but he replied that, "We want to expand our economic space. Entering into FTAs with all of these economies is a means to achieve these ends." ${ }^{81}$ And Koh did not see the USSFTA as a substitute for a trade deal between ASEAN and the United States, but as a stepping stone toward such an accord.

Koh was later asked by the author, "Is it fair to describe this negotiation as a campaign with multiple fronts? There was an internal Singapore front, an executive branch front, a congressional 
front, a business/industrial front in the U.S., and a civil society/union/environmental/human rights front ... is the concept of a negotiation campaign relevant?"

Koh replied, "I think a campaign would be an accurate way to describe it. And it is because America is a unique democracy. If we were negotiating an FTA with China, or with India or Japan, we wouldn't have to do any of these things, but in the case of America, if we had not campaigned on all fronts ... the FTA would not have sailed through Congress the way it did." 82

Echoing Koh's sentiment, Ambassador Chan wrote that the success of the FTA was the result of a, "comprehensive and well coordinated strategy," with success determined by the fact that, "our outreach was early, deep, and wide." 83

The rewards have been evident. Singapore could hope to reap \$250 million in tariff savings, \$51 million per year in import tax relief, relaxed travel restrictions on Singaporean citizens entering the United States, and expanded foreign direct investment from one of its largest trading partners. ${ }^{84}$ All of it stemmed from Koh's indefatigable drive to achieve an agreement. To Koh, it was an affirmation of the "shining symbol of the close partnership which exists between our two countries," and the attainment of a great dream..$^{85}$

\section{Concluding Observations.}

If only for analytic tractability, the great bulk of negotiation analysis tends to prespecify the players and their interests and focus on the interaction process "at the table." (See Lax and Sebenius 2006.) Loosely speaking in this case, such an analytic focus could be visualized as in Figure 2 in which the "game" is "Koh v. Ives."

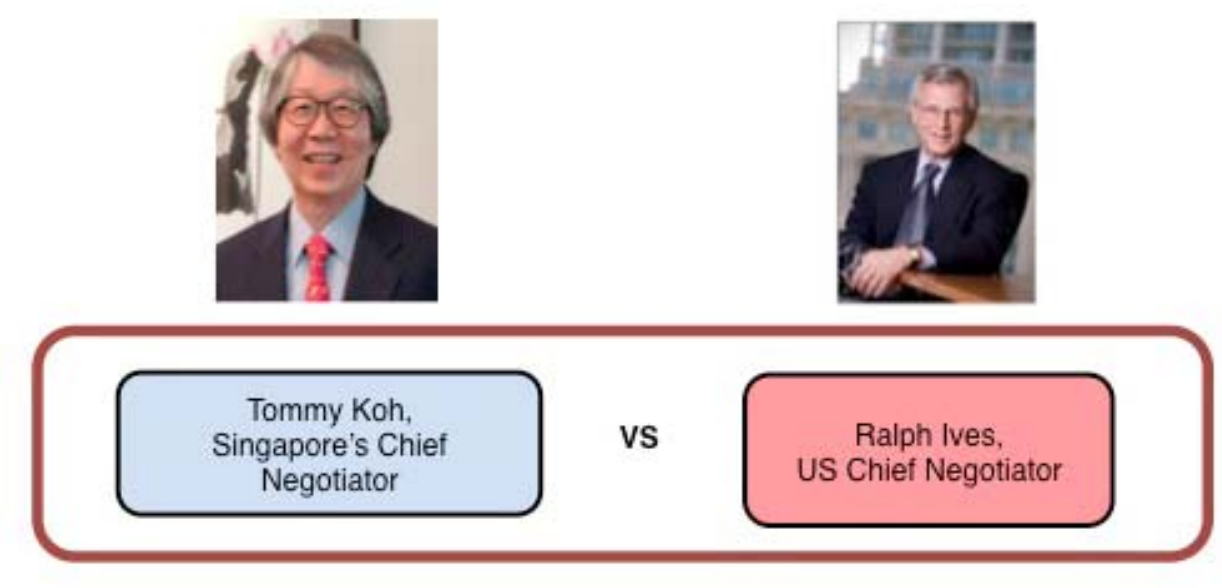

Figure 2: Nä̈ve View of the USSFTA Negotiation Process

Evidently, Figure 2 is something of a straw man. Analysis of these negotiations that took place within this frame would be hopelessly incomplete, even incoherent. The reality of the USSFTA negotiations is far more dynamic and evolutionary, starting with an intention, followed by purposive (and lucky) action to set up the far more complex situation as loosely represented in Figure 3, which itself is greatly simplified compared to the real situation. 


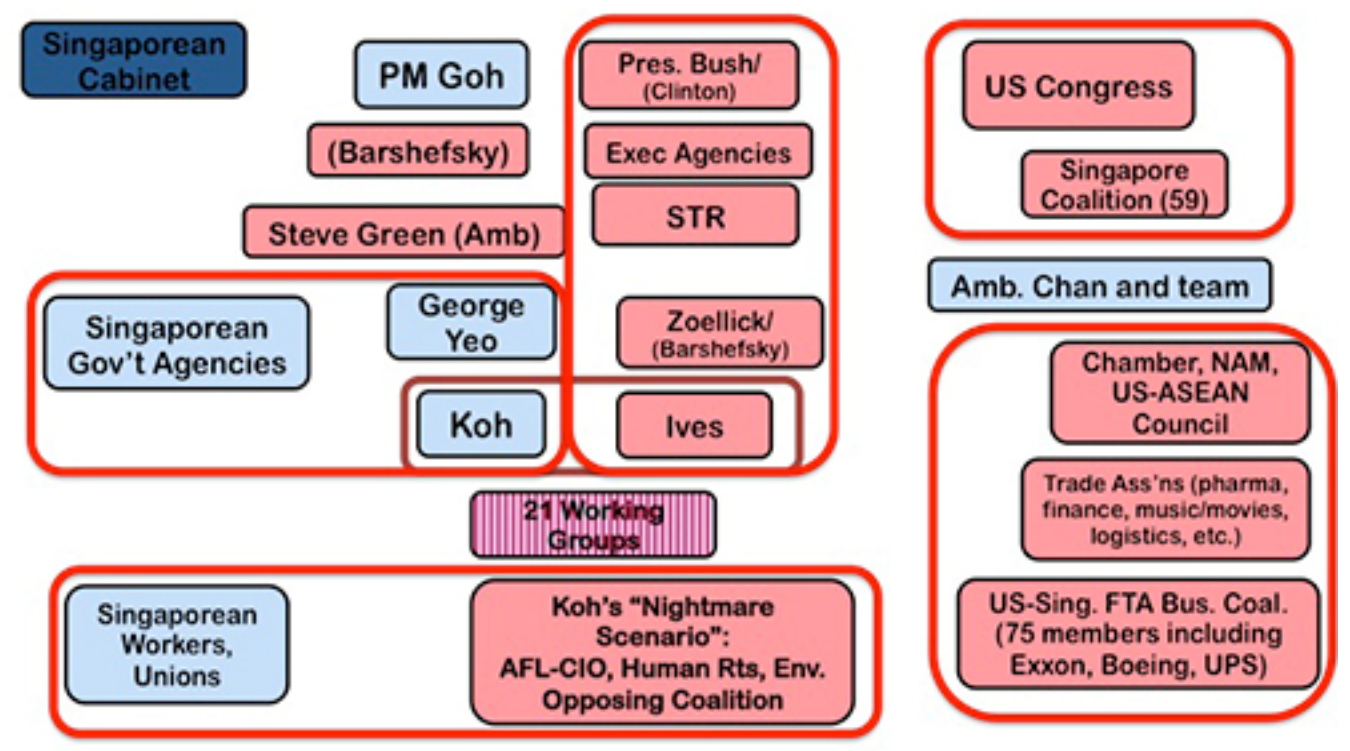

Figure 3: A Five-Front Negotiation USSFTA Campaign

The schematic of Figure 3 roughly - but far more faithfully to the reality--portrays the five front campaign as ultimately orchestrated by Koh and Chan: the U.S. Executive Branch, Congress, U.S. business, a potential "nightmare" group of parties, and the "internal" Singaporean players. Within each of these fronts, and orchestrated among them, complex negotiations took place that set the stage for the ultimate target deal signing by President Bush and Prime Minister Goh.

What is the special value of this case study and analytic frame? First, the USSFTA negotiations are of intrinsic substantive and policy interest. Second, by picking apart the reality of this complex interaction over time, this analysis demonstrates the inadequacy of more standard analysis - from two-level games to free form multiparty dealings - to capture critical features of the negotiation process. Third, it seeks to show the potentially clarifying power of a negotiation campaign framework, both descriptively and prescriptively.

By highlighting the target deal and support required for agreement and implementation, it is possible for an analyst or protagonist to map backwards from this goal to determine a range of actually and potentially involved parties. Because this group of parties is typically so large, the concept of "fronts" can strategically simplify the interaction and give rise to a set of questions quite different from a simpler form of negotiation. On the way to a sustainable winning coalition while dealing with blockers, the campaigner confronts issues of front interdependency, sequential versus parallel negotiating emphasis, as well as information revelation at different stages of the process. When the unit of analysis shifts from the deal to the campaign, a valuable new apparatus must be developed. 


\section{Endnotes}

1 Jayakumar, S. Diplomacy: A Singapore Experience. (Singapore: Straits Times Press, 2011), pp. 11-12.

2 Sebenius, James K. and Laurence A. Green. “Tommy Koh: Background and Major Accomplishments of the ‘Great Negotiator, 2014,'” HBS Working Paper No. 14-049.

${ }^{3}$ Koh, Tommy T. B. and S Jayakumar. "The Negotiating Process of the Third United Nations Conference on the Law of the Sea," in the United Nations Convention on the Law of the Sea, 1982, A Commentary (Volume 1) edited by Myron H. Nordquist. The Hague: Martinus Nijhoff. 1985.; Koh, T.T.B., "A Constitution for the Oceans," pp. 50-56 of The Tommy Koh Reader: Favourite Essays and Lectures. Singapore: World Scientific Publishing. 2013.

4 Tommy Koh, interview by author, Cambridge, MA, April 9, 2014

${ }^{5}$ Koh, Tommy Thong Bee, and Li Lin Chang. “The USSFTA: a Personal Perspective.” In The United States Singapore Free Trade Agreement: Highlights and Insights, 293. World Scientific. 2004.

${ }^{6}$ Koh, T.T.B., "Memories of My Father," in The Tommy Koh Reader: Favourite Essays and Lectures. Singapore. World Scientific Publishing. 2013. pp. 5-7.

${ }^{7}$ Koh, T.T.B., “A Letter From Dean Griswold," in The Tommy Koh Reader: Favourite Essays and Lectures. Singapore. World Scientific Publishing. 2013. pp. 44-9; Tommy Koh Reader, pp. 517-18.

${ }^{8}$ Koh, T.T.B., “Singapore's Foreign Policy," in The Tommy Koh Reader: Favourite Essays and Lectures. Singapore. World Scientific Publishing. 2013. pp. 185-90; Tommy Koh Reader, pp. 517-18.

${ }^{9}$ Statistical Tables from Yearbook: Population, Singapore: Singapore Department of Statistics, 2014; also page 115 of Koh, T.T.B., “Lee Kuan Yew's Foreign Policy Legacy”; Tommy Koh Reader, pp. 115-20

${ }^{10}$ Koh, T.T.B., "Size is Not Destiny," in The Tommy Koh Reader: Favourite Essays and Lectures. Singapore. World Scientific Publishing. 2013. p. 222.; also Koh and Chang.

${ }^{11}$ Koh, T.T.B., "Singapore's Foreign Policy," in The Tommy Koh Reader: Favourite Essays and Lectures. Singapore. World Scientific Publishing. 2013. pp. 185-90.

12 Koh, T.T.B., “My Adventure in International Law.” Colloquium on Singapore and International Law: the Early Years. 2009. Reprinted in Koh, T.T.B., "My Adventure with International Law," pp. 359-71 of The Tommy Koh Reader: Favourite Essays and Lectures. Singapore: World Scientific Publishing. 2013.

13 Sebenius and Green.

14 The Tommy Koh Reader, pp. 517-29

15 USSFTA, p. 5.; Jayakumar, p. 136; Hodson pp. 5-7, 16.

16 Tommy Koh, interview by author, Cambridge, MA, April 9, 2014

17 Tommy Koh, interview by author, Cambridge, MA, April 9, 2014

18 Tommy Koh, interview by author, Cambridge, MA, April 9, 2014

19 Quick Facts: The U.S.-Singapore Free Trade Agreement, (Washington, D.C.: Office of the United States Trade Representative) Accessed: August 3, 2014. http://ustr.gov/about-us/press-office/fact-sheets/archives/2003/may/quick-facts-us-singaporefree-trade-agreement.; Koh, Tommy Thong Bee, and Li Lin Chang. “The USSFTA: a Personal Perspective." In The United States Singapore Free Trade Agreement: Highlights and Insights, 293. World Scientific. 2004.

${ }^{20}$ Tommy Koh, interview by author, Cambridge, MA, April 9, 2014; USSFTA, pp. 7-10.

${ }^{21}$ Interview by author, Cambridge, MA, April 9, 2014.

22 Sebenius, James K. “Transcript of the Great Negotiator 2014 Proceedings.” Cambridge, MA: Harvard Law School Program on Negotiation. April 10, 2014..; USSFTA, pp. 6-7.

23 Sebenius

24 Sebenius 
25 Tommy Koh, interview by author, Cambridge, MA, April 9, 2014

26 Sebenius, p. 3.

${ }^{27}$ Koh, Tommy. Interview by author. Cambridge, MA: Harvard Business School April 9, 2014.

${ }^{28}$ Koh, Tommy Thong Bee and Li Lin Chang. “The USSFTA: a Personal Perspective." in The United States Singapore Free Trade Agreement: Highlights and Insights, World Scientific, 2004, p. 14.

${ }^{29}$ HBS interview, April 9, 2014

${ }^{30}$ HBS interview, April 9, 2014

31 Quick Facts: The U.S.-Singapore Free Trade Agreement, (Washington, D.C.: Office of the United States Trade Representative) Accessed: August, 2014. http:// www.ustr.gov/about-us/press-office/fact-sheets/archives/2003/may/quick-facts-ussingapore-free-trade-agreement.; USSFTA, pp. 10-13.

${ }^{32}$ Koh, T.T.B., “De Tocqueville Revisited: American Politics Viewed from a Foreign Perspective.” Reprinted in Koh, T.T.B., The Tommy Koh Reader: Favourite Essays and Lectures. Singapore: World Scientific Publishing. 2013. p. 199

33 Quick Facts; USSFTA, pp. 3-22

34 HBS interview, April 9, 2014

35 USSFTA, p. 12.

36 USSFTA p. 12.

37 Ives, Ralph. “The USSFTA: Personal Perspectives on the Process and Results." in The United States Singapore Free Trade Agreement: Highlights and Insights, edited by Tommy Thong Bee Koh and Li Lin Chang. Singapore: World Scientific, 2004 , p. 24.

${ }^{38}$ Ives, p. 24.

${ }^{39}$ Ives, pp. 24-5.

40 State Department bio http:/ /2001-2009.state.gov/outofdate/bios/y/42449.htm acc Sep29

41 USSFTA, p. 4.

42 USSFTA, p. 15

43 USSFTA, 180.

44 Ives, p. 32.

45 Ives, pp. 25.

46 USSFTA, pp. 15-17.

47 Chan, p. 168.

48 Chan, p. 174.

${ }^{49}$ USSFTA, pp. 12-13.

50 USSFTA, p. 12.

${ }^{51}$ Chan, p. 166.

52 Chan, pp. 166-7.

53 Conley, p. 191.

54 Conley, p. 192.

55 Chan, p. 167.

56 USSFTA, pp. 12-13., 167. 
${ }^{57}$ HBS interview, April 9, 2014

58 Lal, Vinay, "The Flogging of Michael Fay: Culture of Authoritarianism." Economic and Political Weekly, Vol. 29 , No. 23 (June 1994): 1386-1388. Pristay, Chris, “At Long Last, Gum is Legal in Singapore, But There Are Strings," Wall Street Journal, June 4 , 2004: accessed December 4, 2014 http:/ / online.wsj.com/articles/SB108629672446328324

${ }^{59}$ WSJ

${ }^{60}$ HBS interview, April 9, 2014

61 WSJ

62 HBS interview, April 9, 2014

63 Sebenius., p. 5.

64 Sebenius, p. 5.

65 HBS interview, April 9, 2014

66 HBS interview, April 9, 2014

67 Sebenius, p. 5.

68 USSFTA, p. 13.

${ }^{69}$ Sebenius, p. 5.; HBS interview, April 9, 2014

${ }^{70}$ Ives, p. 25.

${ }^{71}$ HBS interview, April 9, 2014

72 Nanto, Dick K. CRS Report for Congress Prepared for Members and Committees of Congress The U.S.-Singapore Free Trade Agreement: Effects After Five Years. Washington D.C.: Congressional Research Service, 2010: 8.

73 USSFTA, pp. 15-16.

${ }^{74}$ USSFTA, p. 21.

${ }^{75}$ HBS interview, April 9, 2014

${ }^{76}$ Chan, p. 171.

${ }^{77}$ Chan, p. 166, 172.

78 U.S. Congress., House, To Authorize Extension of Nondiscriminatory Treatment (Normal Trade Relations Treatment) to the People's Republic of China, HR 4444, 106 ${ }^{\text {th }}$ Congress, (May 24, 2000). http://clerk.house.gov/evs/2000/roll228.xml accessed Dec. 2, 2014.

U.S. Congress., House, North American Free Trade Agreement Implementation Act. HR 3450, 103 ${ }^{\text {rd }}$ Congress, (November 17, 1993). http://clerk.house.gov/evs/1993/roll575.xml accessed Dec. 2, 2014.

${ }^{79}$ USSFTA, p. 20-21.

80 USSFTA, pp. 18-20.

81 HBS interview, April 9, 2014

82 HBS interview, April 9, 2014

83 Chan, p. 174.

${ }^{84}$ USSFTA, pp. 18-20.

${ }^{85}$ USSFTA, p. 22. 


\section{Bibliography}

Chan, Heng Chee. "Lobbying for the United States-Singapore Free Trade Agreement." in The United States Singapore Free Trade Agreement: Highlights and Insights, edited by Tommy Thong Bee Koh and Li Lin Chang. Singapore: World Scientific, 2004, pp. 163-76.

Conley, Jennifer. "Lobbying the American Business Community in Singapore." in The United States Singapore Free Trade Agreement: Highlights and Insights, edited by Tommy Thong Bee Koh and Li Lin Chang. Singapore: World Scientific, 2004, pp. 191-200.

Department of State Archive. "Biography: Robert B. Zoellick." Department of State, United States Government: Washington, D.C., $2005 . \quad$ http://20012009.state.gov/outofdate/bios/y/42449.htm accessed October 3, 2014.

Hodson, Joel, "A Case for American Studies: The Michael Fay Affair, Singapore-US Relations, and American Studies in Singapore." American Studies International, Vol. 41, No. 3 (October 2003): 4-31.

Ives, Ralph. "The USSFTA: Personal Perspectives on the Process and Results." in The United States Singapore Free Trade Agreement: Highlights and Insights, edited by Tommy Thong Bee Koh and Li Lin Chang. Singapore: World Scientific, 2004, pp. 23-32.

Koh, Tommy T. B. \& S Jayakumar. "The Negotiating Process of the Third United Nations Conference on the Law of the Sea," in the United Nations Convention on the Law of the Sea, 1982, A Commentary (Volume 1) edited by Myron H. Nordquist. The Hague: Martinus Nijhoff. 1985.

Koh, Tommy. Interview by author. Cambridge, MA, April 9, 2014.

Koh, Tommy Thong Bee and Li Lin Chang. "The USSFTA: a Personal Perspective." in The United States Singapore Free Trade Agreement: Highlights and Insights, Singapore: World Scientific, 2004.

Koh, T.T.B., "A Constitution for the Oceans," in The Tommy Koh Reader: Favourite Essays and Lectures. Singapore: World Scientific Publishing. 2013.

Koh, T.T.B., "A Letter From Dean Griswold," in The Tommy Koh Reader: Favourite Essays and Lectures. Singapore: World Scientific Publishing. 2013.

Koh, T.T.B., "De Tocqueville Revisited: American Politics Viewed from a Foreign Perspective," in The Tommy Koh Reader: Favourite Essays and Lectures. Singapore: World Scientific Publishing. 2013.

Koh, T.T.B., "Memories of My Father," in The Tommy Koh Reader: Favourite Essays and Lectures. Singapore: World Scientific Publishing. 2013.

Koh, T.T.B., "My Adventure in International Law," in The Tommy Koh Reader: Favourite Essays and Lectures. Singapore: World Scientific Publishing. 2013.

Koh, T.T.B., "Singapore's Foreign Policy," in The Tommy Koh Reader: Favourite Essays and Lectures. Singapore: World Scientific Publishing. 2013.

Koh, T.T.B., "Size is Not Destiny," in The Tommy Koh Reader: Favourite Essays and Lectures. Singapore: World Scientific Publishing. 2013. 
Jayakumar, S, Diplomacy: A Singapore Experience. Singapore: Straits Times Press, 2011.

Lal, Vinay, "The Flogging of Michael Fay: Culture of Authoritarianism." Economic and Political Weekly, Vol. 29, No. 23 (June 1994): 1386-1388

Nanto, Dick K. CRS Report for Congress Prepared for Members and Committees of Congress The U.S.Singapore Free Trade Agreement: Effects After Five Years. Washington D.C.: Congressional Research Service, 2010.

Neo, Gim Huay. "What I Learnt from the U.S. Business Community." in The United States Singapore Free Trade Agreement: Highlights and Insights, edited by Tommy Thong Bee Koh and Li Lin Chang. Singapore: World Scientific, 2004, pp. 177-89.

Pristay, Chris, "At Long Last, Gum is Legal in Singapore, But There Are Strings," Wall Street Journal, June 4, 2004: accessed December 4, 2014 http:/ / online.wsj.com/articles/SB108629672446328324

Quick Facts: The U.S.-Singapore Free Trade Agreement, (Washington, D.C.: Office of the United States Trade Representative) Accessed: August, 2014. http:/ / www.ustr.gov/about-us/pressoffice/fact-sheets/archives/2003/may/quick-facts-us-singapore-free-trade-agreement.

Sebenius, James K. "Transcript of the Great Negotiator 2014 Proceedings." Cambridge, MA: Harvard Law School Program on Negotiation. April 10, 2014.

Sebenius, James K. and Laurence A. Green. "Tommy Koh: Background and Major Accomplishments of the 'Great Negotiator, 2014," HBS Working Paper No. 14-049.

Statistical Tables from Yearbook: Population, Singapore: Singapore Department of Statistics, 2014. http://www.singstat.gov.sg/statistics/browse_by_theme/population.html, accessed, November 2014

University of Texas Libraries, The University of Texas at Austin. Perry Castaneda Library Map Collection, http:/ / www.lib.utexas.edu/maps, accessed August, 2014.

U.S. Congress., House, To Authorize Extension of Nondiscriminatory Treatment (Normal Trade Relations Treatment) to the People's Republic of China, HR 4444, 106 ${ }^{\text {th }}$ Congress, (May 24, 2000). http:/ / clerk.house.gov/evs/2000/roll228.xml accessed Dec. 2, 2014.

U.S. Congress., House, North American Free Trade Agreement Implementation Act. HR 3450, 103 rd Congress, (November 17, 1993). http://clerk.house.gov/evs/1993/roll575.xml accessed Dec. 2, 2014 . 